PNNL-10984

UC $=8400$

Project Technical Information

RECEIVFD

APR 011996

PNL Vitrification Technology

OSTI

Development Project High-Waste

Loaded High-Level Waste Glasses

for High-Temperature Melter: Letter

Report

D. Kim

P. R. Hrma

February 1996

Prepared for

the U.S. Department of Energy

under Contract DE-AC06-76RLO 1830

Pacific Northwest National Laboratory

Richland, Washington 99352

Battelle

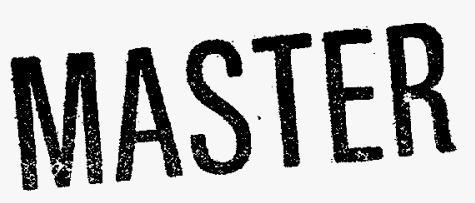


PNNL-10984

UC-810

Project Technical Information

\section{PNL Vitrification Technology Development Project High-Waste Loaded High-Level Waste Glasses for High- Temperature Melter: Letter Report}

D. Kim

P. R. Hrma

February 1996

Prepared for

the U.S. Department of Energy

under Contract DE-AC06-76RLO 1830

Pacific Northwest National Laboratory

Richland, Washington 99352 


\title{
DISCLAIMER
}

This report was prepared as an account of work sponsored by an agency of the United States Government. Neither the United States Government nor any agency thereof, nor Battelle Memorial Institute, nor any of their employees, makes any warranty, express or implied, or assumes any legal liability or responsibility for the accuracy, completeness, or.usefulness of any information, apparatus, product, or process disclosed, or represents that its use would not infringe privately owned rights. Reference herein to any specific commercial product, process, or service by trade name, trademark, manufacturer, or otherwise does not necessarily constitute or imply its endorsement, recommendation, or favoring by the United States Government or any agency thereof, or Battelle Memorial Institute. The views and opinions of authors expressed herein do not necessarily state or reflect those of the United States Government or any agency thereof.

\author{
PACIFIC NORTHWEST NATIÓNAL LABORATORY \\ operated by \\ BATTELLE \\ for the \\ UNITED STATES DEPARTMENT OF ENERCY \\ under Contract DE-AC06-76RLO 1830
}

\author{
Printed in the United States of America \\ Available to DOE and DOE contractors from the \\ Office of Scientific and Technical information, P.O. Box 62, Oak Ridge, TN 37831; \\ prices, availabie from (615) $576-8401$.
}

Available to the public from the National Technical information Service, U.S. Department of Commerce, 5285 Port Royal Rd., Springfield, VA 22161 


\section{IABLE OF CONTENTS}

1.0 INTRODUCTION . . . . . . . . . . . . . . . . . 1

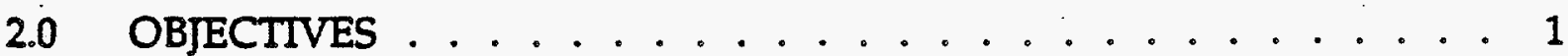

3.0 GLASS FORMULATION APPROACH $\ldots \ldots \ldots \ldots$

4.0 EXPERIMENTAL METHODS $\ldots \ldots \ldots \ldots \ldots \ldots \ldots$

5.0 GLASSES WITH NCAW $\ldots \ldots \ldots \ldots \ldots$

6.0 GLASSES WTTH BLEND WASTE $\ldots \ldots \ldots \ldots \ldots$

7.0 CONCLUSIONS $\ldots \ldots \ldots \ldots \ldots \ldots \ldots$

8.0 REFERENCES . . . . . . . . . . . . . . 13 


\section{LIST OF FIGURES}

1. Predicted Liquidus Temperature ( $\mathrm{T}_{\mathrm{L}}$ ) of (a) Spinel and (b) $\mathrm{Zr}$-Containing Phases Versus Predicted Melting Temperature $\left(T_{M}\right)$ for Glasses with $50 \mathrm{wt} \% \mathrm{NCAW}+50 \mathrm{wt} \%\left[(100-\mathrm{x}) \mathrm{SiO}_{2}+x \mathrm{Y}\right]$, Where $\mathrm{Y}$ Represents $\mathrm{B}_{2} \mathrm{O}_{3}$, $\mathrm{Na}_{2} \mathrm{O}$, or $\mathrm{Li}_{2} \mathrm{O}$ and $x$ Is the wt\% of $\mathrm{Y}$ in the Additive Mix. The Value of $x$ Varied by 2 wt\% for Each Data Point from 0 to 14 wt\%.. . . . . . . . 


\section{LIST OF TABLES}

1. Single- and Multi-Component Constraints for Glass Property/ Composition Models . . . . . . . . . . . . . . . 3

2. Compositions (in mass fraction) of Simulated NCAW (Neutralized Current Acid Waste) and Blend Waste . . . . . . . . . . . 5

3. Crystallinity of Glasses Containing $50 \mathrm{wt} \% \mathrm{NCAW}$ with Addition of $\mathrm{SiO}_{2}$ Only or $\mathrm{SiO}_{2}$ and $\mathrm{B}_{2} \mathrm{O}_{3}$ (Preliminary Study) . . . . . . 6

4. Viscosity and Crystallinity of Glasses Containing $50 \mathrm{wt} \%$ NCAW with Addition of $\mathrm{SiO}_{2}$ and $\mathrm{Na}_{2} \mathrm{O}$ or $\mathrm{Li}_{2} \mathrm{O} \ldots \ldots . . . . . .99$

5. Viscosity and Electrical Conductivity of Glass N508 As a Function of Temperature ................. 10

6. Viscosity and Crystallinity in Glasses Containing Blend Waste with Addition of $\mathrm{SiO}_{2}$ Only ................ 12 


\section{$1.0 \quad$ INTRODUCTION}

For vitrification of high-level wastes (HLW) at the Hanford Site, a Joule-heated overflow type melter with bottom draining capability and capable of operating at temperatures up to $1500^{\circ} \mathrm{C}$ is being developed. The original proposed Hanford Waste Vitrification Plant (HWVP) melter used a $1150^{\circ} \mathrm{C}$ processing temperature and was tested using glasses with up to $28 \mathrm{wt} \%$ waste oxide loading for NCAW (Neutralized Current Acid Waste). The goal of the high-temperature melter (HTM) is the volume reduction of the final product and increase of the waste processing rate by processing high-waste loaded glasses at higher temperatures. This would dramatically decrease waste disposal and processing costs.

The aim of glass development for the HTM is to determine compositions and melting temperatures for processible and acceptable glasses with a high waste loading. Glass property/composition models for viscosity and liquidus temperature developed in the Glass Envelope Definition (GED) study (Hrma et al. 1994) were used. The results of glass formulation and experimental testing are presented for NCAW and DST/SST (Double-Shell Tank/Single-Shell Tank) Blend waste. Although the purpose of this report was to summarize the glass development study with Blend waste only, the results with NCAW were needed because glass development with Blend waste was based on the results from the glass development study with NCAW.

This work was performed in support of HTM development program (1.2.2.04.19).

\subsection{OBIECTIVES}

The objectives of this study are

- to develop the glass formulation approach for the HTM, and

- to determine the composition and melting temperature of a glass with $50 \mathrm{wt} \%$ NCAW for the first HTM runs and the maximum waste loading in glasses with DST/SST Blend waste for the future HTM runs. 


\subsection{GLASS FORMULATION APPROACH}

An important property required for glass processiblility in a continuous melter is melt crystallinity. Additionally, the durability of the HLW glass determines whether it is acceptable for disposal. Because Hanford high-level wastes are mainly composed of refractory oxides, such as $\mathrm{ZrO}_{2}, \mathrm{Al}_{2} \mathrm{O}_{3}$, and $\mathrm{Fe}_{2} \mathrm{O}_{3}$, their waste loading is limited by crystallinity before the durability limit is reached (Fini and Hrma 1994). HLW glasses, especially those with high waste loading and high melting temperature have reduced alkali and boron oxides content, which also improves durability. For this reason, the formulation of HLW glasses for the HTM focuses on the melt crystallinity.

Models are available for various glass properties, such as viscosity, durability, liquidus temperature, and electrical conductivity (Hrma et al. 1994). The models have been developed within the composition range defined by single- and multicomponent constraints, shown in Table 1, and thus, an extrapolation to compositions beyond these constraints may generate uncertain predictions. Typically, the compositions of high-temperature glasses fall outside of at least one of these constraints. In addition, models for viscosity and electrical conductivity are validated only within temperatures between 950 and $1250^{\circ} \mathrm{C}$ because these models were developed for the $1150^{\circ} \mathrm{C}$ melter, while the intended operating temperature of the HTM is generally higher than $1250^{\circ} \mathrm{C}$. Because of complexities involved in the crystallization of glasses (Hrma et al. 1994, Kim and Hrma 1994), liquidus temperature models are even further limited in terms of glass composition and temperature ranges.

Glass liquidus temperature constraint for Hanford melters has traditionally been $T_{L}<T_{M}-100^{\circ} C_{\text {, }}^{*}$ where $T_{L}$ is the liquidus temperature and $T_{M}$ is the melter processing temperature (melting temperature). The predicted $T_{M}$ was defined as the temperature at which the predicted viscosity is $4 \mathrm{~Pa} \cdot \mathrm{s}$ (except for glasses in the preliminary tests). An effort was made to achieve the highest waste loading compatible with the requirement that $T_{L}<T_{M}-100^{\circ} \mathrm{C}$. Because of their limited

\footnotetext{
* Hanford Waste Vitrification Plant Project Technical Data Pakage, WHC-SD-HWV-DP-001, Rev. 6, Westinghouse Hanford Company, Richland, WA, 1992.
} 
TABLE 1. Single- and Multi-Component Constraints for Glass Property/Composition Models

(a) Single-component constraints

\begin{tabular}{|c|c|c|}
\hline Component & Lower limit (wt\%) & Upper limit (wt\%) \\
\hline $\mathrm{SiO}_{2}$ & 42 & 57 \\
\hline $\mathrm{B}_{2} \mathrm{O}_{3}$ & 5 & 20 \\
\hline $\mathrm{Na}_{2} \mathrm{O}$ & 5 & 20 \\
\hline $\mathrm{Li}_{2} \mathrm{O}$ & 1 & 7 \\
\hline $\mathrm{CaO}$ & 0 & 10 \\
\hline $\mathrm{MgO}$ & 0 & 8 \\
\hline $\mathrm{Fe}_{2} \mathrm{O}_{3}$ & 0.5 & 15 \\
\hline $\mathrm{Al}_{2} \mathrm{O}_{3}$ & 0 & 17 \\
\hline $\mathrm{ZrO}_{2}$ & 0 & 13 \\
\hline "Others" & 1 & 10 \\
\hline \multicolumn{3}{|c|}{ (b) Multi-component constraints } \\
\hline \multicolumn{2}{|c|}{ Oxide sum (wt\%) or ratio } & Upper Limit \\
\hline \multicolumn{2}{|c|}{$\mathrm{CaO}+\mathrm{MgO}$} & 10 \\
\hline \multicolumn{2}{|c|}{$\mathrm{Al}_{2} \mathrm{O}_{3}+\mathrm{ZrO}_{2}$} & 18 \\
\hline \multicolumn{2}{|c|}{$\mathrm{CaO}+\mathrm{MgO}+\mathrm{ZrO}_{2}$} & 18 \\
\hline \multicolumn{2}{|c|}{$\mathrm{Fe}_{2} \mathrm{O}_{3}+\mathrm{Al}_{2} \mathrm{O}_{3}+\mathrm{ZrO}_{2}+$ Others } & 24 \\
\hline \multicolumn{2}{|c|}{$\mathrm{Al}_{2} \mathrm{O}_{3} / \mathrm{SiO}_{2}$} & 0.33 \\
\hline
\end{tabular}

applicability, the models were only used as initial predictive tools, especially those for liquidus temperature, and it was necessary to test the glasses by measuring their properties in the laboratory. 


\subsection{EXPERIMENTAL METHODS}

Table 2 shows the simulated composition of NCAW and Blend waste used in this study. NCAW has been well characterized and extensively used in past melter runs. The Blend waste composition represents the estimated average composition of all the Hanford double-shell tank (DST) and single-shell tank (SST) wastes. The composition is expressed in weight percents of nine major oxide components and "Others," the "Others" component being comprised of the remaining waste components.

For each glass, the nine major components were batched as oxides or carbonates, while "Others" were batched together in constant proportions. Each glass was melted at the temperature for a predicted viscosity of $4 \mathrm{~Pa} \cdot \mathrm{s}$ (except for glasses in the preliminary tests) for $1.5 \mathrm{~h}$ in a platinum crucible, under a lid, using an electrically heated resistance furnace. For better homogeneity, the glass was crushed and remelted for $1.5 \mathrm{~h}$ under the same conditions. The glass for the crystallinity test was poured into a $2 \times 2 \times 7 \mathrm{~cm}$ bar, air quenched, and annealed for $2 \mathrm{~h}$, followed by furnace cooling. The remaining glass was poured onto a steel plate and air quenched. This glass was used for viscosity measurement.

Crystallinity was evaluated in as-melted samples and 24-h heat treated samples at $T_{M}$ and $T_{M}-100^{\circ} \mathrm{C}$. Cubical spicimens were cut from the glass bar and placed in a Pt-foil box in a preheated furnace for the heat treatment. Thin sections, prepared from the glass samples and mounted in polymer resin, were examined using an optical microscope with both reflected and transmitted light to determine the type of crystalline phases present. The volume fraction of crystals were estimated by an Image Analysis System attached to the optical microscope. The chemical composition of the crystalline phases was qualitatively determined by SEM/EDS (Scanning Electron Microscopy/Energy. Dispersive Specroscopy).

Viscosity was measured using a rotating spindle viscosmeter at temperatures in the range of $T_{M} \pm 150^{\circ} \mathrm{C}$. Electrical conductivity and 7-day PCT (Product Consistency Test) (Janzen and Bibler 1990) elemental releases were determined for

\footnotetext{
"Memo, from Bob Watrous, WHC, to Pavel Hrma, PNL, "Composition Limits for Blended DST \& SST Waste Glasses;" dated June 11, 1993.
} 
IABLE 2. Compositions (in mass fraction) of Simulated NCAW (Neutralized Current Acid Waste) and Blend Waste

\begin{tabular}{crc}
\hline Component & NCAW & Blend Waste \\
\hline $\mathrm{SiO}_{2}$ & 4.02 & 12.37 \\
$\mathrm{~B}_{2} \mathrm{O}_{3}$ & 0.01 & 0.09 \\
$\mathrm{Na}_{2} \mathrm{O}$ & 21.35 & 24.67 \\
$\mathrm{Li}_{2} \mathrm{O}$ & & \\
$\mathrm{CaO}$ & 0.79 & 2.52 \\
$\mathrm{MgO}$ & 0.20 & 0.09 \\
$\mathrm{Fe}_{2}$ & 28.13 & 13.60 \\
$\mathrm{Al}_{2}$ & 9.01 & 9.74 \\
$\mathrm{ZrO}_{2}$ & 15.07 & 8.75 \\
"Others" & 21.43 & 28.16 \\
\hline Total & 100.00 & 100.00 \\
\hline
\end{tabular}

"Others" components

\begin{tabular}{|c|c|c|}
\hline $\begin{array}{l}\mathrm{BaO} \\
\mathrm{Bi}_{2} \mathrm{O}_{3} \\
\mathrm{CdO} \\
\mathrm{CeO}_{2} \\
\mathrm{Cr}_{2} \mathrm{O}_{3} \\
\mathrm{Cs}_{2} \mathrm{O}^{2} \\
\mathrm{CuO} \\
\mathrm{F} \\
\mathrm{La}_{2} \mathrm{O}_{3} \\
\mathrm{MnO}_{2} \\
\mathrm{MoO}_{3} \\
\mathrm{Nd}_{2} \mathrm{O}_{3} \\
\mathrm{NiO} \\
\mathrm{P}_{2} \mathrm{O}_{5} \\
\mathrm{PdO} \\
\mathrm{Pr}_{6} \mathrm{O}_{11} \\
\mathrm{Rb}_{2} \mathrm{O} \\
\mathrm{Rh}_{2} \mathrm{O}_{3} \\
\mathrm{RuO}_{2} \\
\mathrm{SO}_{3} \\
\mathrm{Sm}_{2} \mathrm{O}_{3} \\
\mathrm{SrO}_{3} \\
\mathrm{WO}_{3} \\
\mathrm{Y}_{2} \mathrm{O}_{3}\end{array}$ & $\begin{array}{l}0.38 \\
2.88 \\
0.58 \\
0.48 \\
0.58 \\
0.58 \\
1.15 \\
2.40 \\
0.58 \\
1.15 \\
4.73 \\
2.21 \\
0.38 \\
0.19 \\
0.38 \\
0.19 \\
0.19 \\
0.58 \\
1.06 \\
0.19 \\
0.38 \\
0.19\end{array}$ & $\begin{array}{r}2.75 \\
0.11 \\
3.38 \\
1.06 \\
\\
0.68 \\
0.53 \\
2.25 \\
0.09 \\
12.04 \\
2.81 \\
1.59\end{array}$ \\
\hline Subtotal & 21.43 & 28.16 \\
\hline
\end{tabular}


the selected "best" glass composition. The viscosity $(\eta)$ and electrical conductivity ( $\varepsilon$ ) data as a function of temperature were fitted to the Arrhenius equation, $\ln (\eta, \varepsilon)$ $=A+B / T$, where $A$ and $B$ are constants, and $T$ is the absolute temperature. The viscosity data at temperatures in this report represent the values calculated from the Arrhenius fits.

\subsection{GLASSES WITH NCAW}

Preliminary tests were conducted for glasses with 45 to $50 \mathrm{wt} \%$ NCAW before the liquidus temperature models were available. Table 3 shows the summary of the preliminary test results on glasses with $50 \mathrm{wt} \%$ NCAW. Glass N501 consisted of waste and $\mathrm{SiO}_{2}$. Glasses $\mathrm{N} 502$ and $\mathrm{N} 503$ also contained $\mathrm{B}_{2} \mathrm{O}_{3}$. These glasses were melted at predicted viscosities different from $4 \mathrm{~Pa}$.s. Their crystallinity was determined only in as-melted samples.

At least 3 vol\% spinel was found in all samples. Glass $\mathrm{N} 503$ had $0.4 \mathrm{vol} \% \mathrm{ZrO}_{2}$ in addition to 3.6 vol\% spinel. If glasses $\mathrm{N} 502$ and $\mathrm{N} 503$ were melted at lower

IABLE 3. Crystallinity of Glasses Containing $50 \mathrm{wt} \% \mathrm{NCAW}$ with Addition of $\mathrm{SiO}_{2}$ Only or $\mathrm{SiO}_{2}$ and $\mathrm{B}_{2} \mathrm{O}_{3}$ (Preliminary Study)

\begin{tabular}{llll}
\hline Glass & $\mathrm{N} 501$ & $\mathrm{~N} 502$ & $\mathrm{~N} 503$ \\
\hline $\mathrm{NCAW}(\mathrm{wt} \%)$ & 50 & 50 & 50 \\
$\mathrm{SiO}_{2}(\mathrm{wt} \%)$ & 50 & 46 & 35 \\
$\mathrm{~B}_{2} \mathrm{O}_{3}(\mathrm{wt} \%)$ & 0 & 4 & 15 \\
$\mathrm{~T}_{\mathrm{M}}\left({ }^{\circ} \mathrm{C}\right)$ & 1450 & 1450 & 1400 \\
Predicted $\eta$ at $\mathrm{T}_{\mathrm{M}}(\mathrm{Pa} \cdot \mathrm{s})$ & 5.1 & 3.0 & 1.0 \\
$\begin{array}{l}\text { Crystallinity (vol\%) in } \\
\quad \text { as melted glass }\end{array}$ & spinel $\sim 5$ & spinel $\sim 3$ & spinel $\sim 3.6$ \\
\hline
\end{tabular}


temperatures corresponding to a predicted viscosity of $4 \mathrm{~Pa} \cdot \mathrm{s}$, their crystallinity would be slightly higher than the values shown in Table 3.

Liquidus temperature models were used to evaluate the effect of additions of the alkali oxides $\mathrm{Na}_{2} \mathrm{O}$ and $\mathrm{Li}_{2} \mathrm{O}$ and $\mathrm{B}_{2} \mathrm{O}_{3}$ on the crystallinity, and to further improve glass composition. Figure 1 shows plots of predicted $T_{L}[(a)$ spinel and (b) $\mathrm{Zr}$ containing phases $\left(\mathrm{ZrSiO}_{4}, \mathrm{ZrO}_{2}\right.$, and $\mathrm{Na} \cdot \mathrm{Zr}$ silicate)] versus $\mathrm{T}_{\mathrm{M}}$ (for predicted viscosity of $4 \mathrm{~Pa} \cdot \mathrm{s}$ ) when the additions of $\mathrm{B}_{2} \mathrm{O}_{3}, \mathrm{Na}_{2} \mathrm{O}$, and $\mathrm{Li}_{2} \mathrm{O}$ were varied. The calculated data points correspond to $2 \mathrm{wt} \%$ steps from 0 up to $14 \mathrm{wt} \%$ (right to left) of each oxide in the additive mix.

Because the composition and melting temperature of the glasses shown in Figure 1 are outside of the model validity range, uncertain predictions, especially for the $\mathrm{T}_{\mathrm{L}}$, are expected. This can be illustrated by a relatively high concentration of spinel found in glass $\mathrm{N} 503$ melted at $1400^{\circ} \mathrm{C}$ : the predicted $\mathrm{T}_{\mathrm{L}}$ of spinel in this glass was $1050^{\circ} \mathrm{C}$ (Figure 1). Therefore, the information regarding the "relative" effect of each component on the liquidus temperature was used to aid glass formulation. Figure 1 shows that the $T_{L}$ decreases as melting temperature decreases with the addition of these components except for the effect of $\mathrm{B}_{2} \mathrm{O}_{3}$ on the $\mathrm{T}_{\mathrm{L}}$ of $\mathrm{Zr}$ containing phases. Addition of $\mathrm{Na}_{2} \mathrm{O}$ was most effective for spinel and $\mathrm{Li}_{2} \mathrm{O}$ for $\mathrm{Zr}$-containing phases, while $\mathrm{B}_{2} \mathrm{O}_{3}$ was least effective for both crystalline forms. This result suggests that the crystallinity observed in glasses N502 and N503 may decrease if $\mathrm{Na}_{2} \mathrm{O}$ or $\mathrm{Li}_{2} \mathrm{O}$ is used instead of $\mathrm{B}_{2} \mathrm{O}_{3}$.

Based on the information from preliminary tests and model predictions on the "relative" component effect, four glasses with $\mathrm{Na}_{2} \mathrm{O}$ and $\mathrm{Li}_{2} \mathrm{O}$ addition were formulated and tested. Table 4 summarizes the results.

In the as-melted samples, the glasses with alkali addition (Table 4) exhibited lower crystallinity than the two glasses with $\mathrm{B}_{2} \mathrm{O}_{3}$ addition (Table 3 ). Table 4 shows that the ability for predicting viscosity was resonably good considering that the glass composition and temperature were outside the model validity range.

Crystallinity was lower in as-melted glasses with $T_{M}=1350^{\circ} \mathrm{C}$ (N508 and N509) as compared to those with $\mathrm{T}_{\mathrm{M}}=1400^{\circ} \mathrm{C}$ (N506 and N507). This indicates that the $1350^{\circ} \mathrm{C}$ glasses with a higher alkali content dissolve the spinel crystals formed 

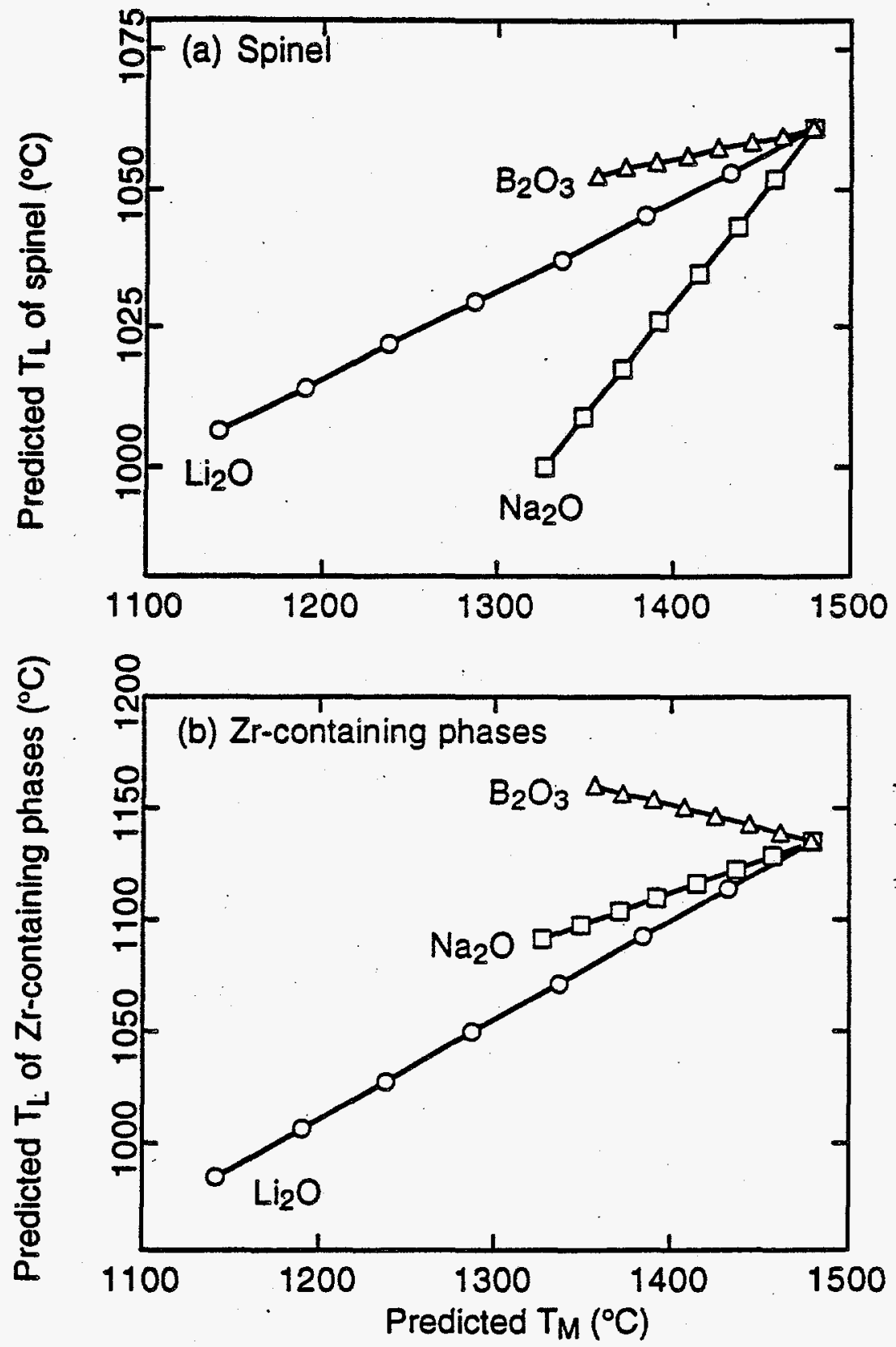

EIGURE 1. Predicted Liquidus Temperature $\left(\mathrm{T}_{\mathrm{L}}\right)$ of (a) Spinel and (b) $\mathrm{Zr}$ Containing Phases Versus Predicted Melting Temperature $\left(T_{M}\right)$ for Glasses with 50 wt $\% \mathrm{NCAW}+50 w t \%\left[(100-x) \mathrm{SiO}_{2}+x Y\right]$, Where $Y$ Represents $\mathrm{B}_{2} \mathrm{O}_{3}, \mathrm{Na}_{2} \mathrm{O}$, or $\mathrm{Li}_{2} \mathrm{O}$ and $x$ Is the $w t \%$ of $Y$ in the Additive Mix. The Value of $\times$ Varied by $2 \mathrm{wt} \%$ for Each Data Point from 0 to 14 wt\%. 
TABLE 4. Viscosity and Crystallinity of Glasses Containing $50 \mathrm{wt} \%$ NCAW with Addition of $\mathrm{SiO}_{2}$ and $\mathrm{Na}_{2} \mathrm{O}$ or $\mathrm{Li}_{2} \mathrm{O}$

\begin{tabular}{|c|c|c|c|c|}
\hline Glass & N506 & N507 & N508 & N509 \\
\hline NCAW (wt\%) & 50 & 50 & 50 & 50 \\
\hline $\mathrm{SiO}_{2}(w t \%)$ & 46.3 & 48.3 & 44.0 & 47.3 \\
\hline $\mathrm{Na}_{2} \mathrm{O}(w t \%)$ & 3.7 & 0 & 6.0 & 0 \\
\hline $\mathrm{Li}_{2} \mathrm{O}(w t \%)$ & 0 & 1.7 & 0 & 2.7 \\
\hline $\mathrm{T}_{\mathrm{M}}\left({ }^{\circ} \mathrm{C}\right)$ & 1400 & 1400 & 1350 & 1350 \\
\hline \multicolumn{5}{|l|}{ Viscosity Coefficients* } \\
\hline A & -14.15 & -12.85 & -14.93 & -13.97 \\
\hline $\mathrm{B}(\mathrm{K})$ & 26716.79 & 24122.39 & 27376.12 & 25080.41 \\
\hline Measured $\eta$ at $T_{M}(\mathrm{~Pa} \cdot \mathrm{s})^{* *}$ & 6.2 & 4.8 & 6.9 & 4.4 \\
\hline \multicolumn{5}{|l|}{ Crystallinity (volume \%) } \\
\hline as-melted & $\sim 1.5$ & $\sim 2.8$ & $<0.1$ & $\sim 0.2$ \\
\hline $24 \mathrm{~h}$ at $\mathrm{T}_{M}$ & 0 & $<0.1$ & $<0.1$ & 0 \\
\hline $24 \mathrm{~h}$ at $\mathrm{T}_{\mathrm{M}}-100^{\circ} \mathrm{C}$ & $<0.1$ & $\sim 0.2$ & 0 & $\sim 0.5$ \\
\hline
\end{tabular}

*Obtained from Arrhenius fit, $\ln (\eta)=A+B / T$, of experimental data. **Predicted viscosity was $4 \mathrm{~Pa} \cdot \mathrm{s}$ at melting temperature for all glasses. ***Spinel was the only crystalline phase observed.

during the initial melting faster than the $1400^{\circ} \mathrm{C}$ glasses. As shown in Table 4 , the crystals almost completely disappeared after 24-h heat treatment at $T_{M}$. The crystallinity after $24 \mathrm{~h}$ at $\mathrm{T}_{M}-100^{\circ} \mathrm{C}$ was $<0.1$ in glasses with $\mathrm{Na}_{2} \mathrm{O}$ (N506 and N508) and a little higher in glasses with $\mathrm{Li}_{2} \mathrm{O}$ (N507 and N509), the latter possibly having a slightly higher liquidus temperature. The glass N508, therefore, was selected for the first SSHTM (Small-Scale High-Temperature Melter) test and subjected to further testing (Smith et al. 1994). 
Table 5 shows the viscosity and electrical conductivity of glass N508 as a function of temperature, obtained from the Arrhenius fits to experimental data. The chemical durability of N508 was determined by a 7-day PCT (Product Consistency Test) Janzen, et al. 1992). The normalized elemental releases were obtained using the formula $r_{i}=m_{i} /\left(F_{i} A\right)$, where $m_{i}$ is the mass of the $i$-th element dissolved in solution $(\mathrm{g}), \mathrm{F}_{\mathrm{i}}$ is the $\mathrm{i}$-th element mass fraction in glass, and $\mathrm{A}$ is the glass surface area $\left(\mathrm{m}^{2}\right)$. The results for $\mathrm{Na}$ and $\mathrm{Si}$ were

$$
\mathrm{r}_{\mathrm{Na}}=0.46 \mathrm{~g} / \mathrm{m}^{2} / 7 \text { days } \quad \mathrm{r}_{\mathrm{Si}}=0.17 \mathrm{~g} / \mathrm{m}^{2} / 7 \text { days }
$$

These results exceed the HLW glass PCT standard, $\mathrm{r}_{\mathrm{Na}}=6.67$ and $\mathrm{r}_{\mathrm{Si}}=1.96\left(\mathrm{~g} / \mathrm{m}^{2} / 7\right.$ days), for EA (Environmental Assessment) glass (Jantzen, et al. 1994).

TABLE 5. Viscosity and Electrical Conductivity of Glass N508 As a Function of Temperature*

\begin{tabular}{ccc}
\hline Temperature $\left({ }^{\circ} \mathrm{C}\right)$ & Viscosity $(\mathrm{Pa} \cdot \mathrm{s})$ & Electrical Conductivity $(\mathrm{S} / \mathrm{m})$ \\
\hline 1250 & 20.99 & 25.00 \\
1300 & 11.86 & 29.47 \\
1350 & 6.94 & 34.40 \\
1400 & 4.19 & 39.78 \\
1450 & 2.61 & 45.62 \\
1500 & 1.66 & 51.91
\end{tabular}

*For viscosity $(\mathrm{Pa} \cdot \mathrm{s}) \mathrm{A}=-14.93$ and $\mathrm{B}=27376.12 \mathrm{~K}$, and for electrical conductivity $(\mathrm{S} / \mathrm{m}) \mathrm{A}=8.40$ and $\mathrm{B}=-7892.54 \mathrm{~K}$ from Arrhenius fit, $\ln (\eta, \varepsilon)=\mathrm{A}+\mathrm{B} / \mathrm{T}$, of experimental data. 


\subsection{GLASSES WITH BLEND WASTE}

Compared with NCAW, the Blend waste had lower concentrations of $\mathrm{Fe}_{2} \mathrm{O}_{3}$ and $\mathrm{ZrO}_{2}$, and a slightly higher concentration of all other components except $\mathrm{MgO}$ (Table 2). This suggests that a higher waste loading can be achieved with the Blend waste. Table 6 shows formulations and test results of four glasses with Blend waste and $\mathrm{SiO}_{2}$ addition within a waste loading range of 57 to $71 \mathrm{wt} \%$. As in NCAW glasses, the predicted melting temperature was determined as that at which the predicted viscosity was $4 \mathrm{~Pa} \cdot \mathrm{s}$; it decreased as the waste loading increased.

Glass B711 (71 wt\% waste loading) contained both spinel and $\mathrm{ZrO}_{2}$ in all samples tested, whereas glass B571 ( $57 \mathrm{wt} \%$ waste loading) did not have any crystals at all. Glass B671 (67 $w t \%$ waste loading) formed spinel in the as-melted sample and $T_{M}$ $100^{\circ} \mathrm{C} 24-\mathrm{h}$ heat treated samples, whereas glass B621 (62 wt\% waste loading) formed spinel in the $T_{M}-100^{\circ} \mathrm{C} 24-h$ heat treated sample only. The size distribution of spinel in this sample $\left(B 621 ; 24\right.$-h heat treated at $\left.T_{M}-100^{\circ} \mathrm{C}\right)$ was different from that in other samples: the total crystallinity of $0.5 \mathrm{vol} \%$ consisted of about $90 \%$ very small $(<1 \mu \mathrm{m})$ and about $5 \%$ large spinel crystals $(10-40 \mu \mathrm{m})$. The size of spinel crystals in other samples ranged from 1 to $10 \mu \mathrm{m}$. The small crystals in B621 were, possibly, formed during cooling. If so, glass B621 might be acceptable for HTM. Because the measured viscosity of glass $\mathrm{B} 621$ was $7 \mathrm{~Pa} \cdot \mathrm{s}$ at the melting temperature $1350^{\circ} \mathrm{C}$, the amount of crystals at $T_{M}-100^{\circ} \mathrm{C}$ for $T_{M}$ at measured viscosity of $4 \mathrm{~Pa} \cdot \mathrm{S}$ will be lower. This suggests that a waste loading B621 than $62 \mathrm{wt} \%$ might be possible assuming a requirement of $<0.1 \mathrm{vol} \%$ spinel at $T_{M}-100^{\circ} \mathrm{C}$.

If the HTM can process glasses with up to $1 \mathrm{vol} \%$ spinel crystallization at $T_{M}$ $100^{\circ} \mathrm{C}$, the maximum waste loading may increase to between 67 and $71 \mathrm{wt} \%$ : glass B671 (67 wt\% waste loading) had $0.8 \mathrm{vol} \%$ spinel at $T_{M}-100^{\circ} \mathrm{C}$. However, it is possible that the processing rate of glasses may become unacceptably slow at a high waste loading of 67 to $71 \mathrm{wt} \%$. The possibility of slow melting rate may be indicated by the 0.8 vol\% spinel in an as-melted sample, which dissolve after $24-\mathrm{h}$ heat treatment at $T_{M}$. 
TABLE 6. Viscosity and Crystallinity in Glasses Containing Blend Waste with Addition of $\mathrm{SiO}_{2}$ Only

\begin{tabular}{lcccc}
\hline \multicolumn{1}{c}{ Glass } & $\mathrm{B} 571$ & $\mathrm{~B} 621$ & $\mathrm{~B} 671$ & $\mathrm{~B} 711$ \\
\hline Blend waste (wt\%) & 57 & 62 & 67 & 71 \\
$\mathrm{SiO}_{2}$ (wt\%) & 43 & 38 & 33 & 29 \\
$\mathrm{~T}_{\mathrm{M}}\left({ }^{\circ} \mathrm{C}\right)$ & 1400 & 1350 & 1300 & 1250 \\
Viscosity Coefficients* & & & & \\
$\quad \mathrm{A}$ & -13.36 & -13.87 & -14.18 & -14.17 \\
$\mathrm{~B}(\mathrm{~K})$ & 25835.63 & 25667.56 & 25164.83 & 24286.19 \\
Measured $\eta$ at $\mathrm{T}_{\mathrm{M}}(\mathrm{Pa} \cdot \mathrm{s})^{* *}$ & 8.0 & 7.0 & 6.2 & 5.9 \\
Crystallinity (volume \%)*** & & & & \\
$\quad$ as-melted & 0 & 0 & $\sim 0.8$ & $\sim 0.4$ \\
& & & & $\mathrm{ZrO}_{2} \sim 0.2$ \\
24 h at $\mathrm{T}_{\mathrm{M}}$ & 0 & 0 & 0 & $\mathrm{ZrO}_{2}<0.1$ \\
$24 \mathrm{~h}$ at $\mathrm{T}_{\mathrm{M}}-100^{\circ} \mathrm{C}$ & 0 & $\sim 0.5^{\wedge}$ & $\sim 0.8$ & $\sim 1.2$ \\
& & & & $\mathrm{ZrO}_{2} \sim 1.2$ \\
& & & & unidentified $\sim 5$ \\
\hline
\end{tabular}

* Obtained from Arrhenius fit, $\ln (\eta)=A+B / T$, of experimental data.

**Predicted viscosity was $4 \mathrm{~Pa}$-s at melting temperature for all glasses.

***Spinel crystals unless otherwise specified.

$\wedge$ Consited of $0.05 \%$ large spinel $(10-40 \mu \mathrm{m})$ and $0.45 \%$ very small spinel $(<1 \mu \mathrm{m})$. In other glasses, the spinel crystals were between 1 and $10 \mu \mathrm{m}$.

The estimated composition of Blend waste has been updated since this work was initiated. The new Blend waste composition ${ }^{*}$ is slightly different from the one

\footnotetext{
* Letter, R. W. Powell, WHC, to J. M. Creer, PNL, "Double-Shell Tank/Single-Shell Tank Waste Blend Composition for High-Level Waste Vitrification Process Testing," 9452712, received May 19, 1994.
} 
used in this study. The new Blend waste is expected to allow waste loadings between 60 and $65 \mathrm{wt} \%$ if $<0.1 \mathrm{vol} \%$ of spinel is acceptable for HTM.

\subsection{CONCLUSIONS}

Glass formulations for HTM from two Hanford waste types were formulated using property/composition models, and tested experimentally. Different approaches were used for different waste types: for NCAW, the glass development effort was focused on finding the optimum additive at a target waste loading of $50 \mathrm{wt} \%$, and for Blend waste, the additive was fixed as $\mathrm{SiO}_{2}$ only, and the waste loading was varied from 57 to $71 \mathrm{wt} \%$, to find the maximum waste loading. An NCAW glass acceptable for repository and processable in the HTM was developed by adding the $\mathrm{SiO}_{2}$ and $\mathrm{Na}_{2} \mathrm{O}$, and is being planned to be used in the first melter run (SSHTM-1). The maximum waste loading that can be achieved with $<0.1$ vol\% crystallinity after $24 \mathrm{~h}$ at $\mathrm{T}_{M}-100^{\circ} \mathrm{C}$ in the Blend waste glass was determined to be between 60 and $65 \mathrm{wt} \%$, with only $\mathrm{SiO}_{2}$ as an additive.

\subsection{REFERENCES}

Fini, P. T. and P. Hrma. Maximization of Waste Loading for a Vitrified Hanford High-Activity Simulated Waste to be published in Ceramic Transactions, 1994.

Hrma, P. R., G. F. Piepel, M. J. Schweiger, D. E. Smith, D. Kim, P. E. Redgate, J. D. Vienna, C. A. LoPresti, D. B. Simpson, D. K. Peeler, and M. H. Langowski. (Draft, May 1994). Property/Composition Relationships for Hanford Waste Vitrification Plant Glasses-Results through CVS-II Phase 4 USDOE Report, Pacific Northwest Laboratory, Richland, WA.

Janzen, C. M., N. E. Bibler, D. C. Beam, W. G. Ramsay, and B. J. Waters. 1992. Nuclear Waste Product Consistency Test (PCT) Method - Version 5.0 USDOE Report WSRC-TR-90-539, Rev. 2, Westinghouse Savannah River Co; Aiken, SC.

Kim, D. and P. Hrma. Models for.Liquidus Temperature of Nuclear Waste Glasses, to be published in Ceramic Transactions, 1994. 
Smith, G. L. et al. 1994. Small-Scale High Temperature Melter - 1 (SSHTM-1) Test Plan. Pacific Northwest Laboratory, Richland, WA.

Janzen, C. M., N. E. Bibler, D. C. Beam, C. L. Crawford, and M. A. Pickett. 1994. Development and Charaterization of the Defence Waste Processing Facility (DWPF) Environmental Assessment (EA) Glass Stand Reference Material (U) Ceramic Transactions, Vol. 39, pp 313-322, American Ceramic Society, Westerville, $\mathrm{OH}$. 